\title{
Primary laparoscopic repair of perforating fishbone injury of the small bowel
}

\author{
Mohamad Zeina 지 , Michael Bath, Georgios Kakaniaris, Pasquale Giordano
}

Whipps Cross University Hospital, Barts Health NHS Trust, London, UK

\section{Correspondence to} Dr Mohamad Zeina; mohamad.zeina@nhs.net

Accepted 16 December 2020

\section{DESCRIPTION}

A 69-year-old man presented to the emergency department with a 2-day history of worsening right iliac fossa pain. He denied any associated nausea, fevers, change in bowel habit, urinary symptoms or recent weight loss. His previous medical history was of hypertension only.

On examination, his abdomen was soft with tenderness in the lower abdomen, but without guarding or percussion tenderness. The initial differential diagnosis at this point included appendicitis or appendagitis. Blood tests on admission were only mildly deranged, with a white cell count of $10.2 \times 10^{9} / \mathrm{L}$ and $\mathrm{C}$ reactive protein of $87 \mathrm{mg} / \mathrm{L}$, while the remainder were within normal range. Due to the persistence of the pain and clinical equipoise, he subsequently underwent a CT scan of the abdomen and pelvis. The scan was initially reported as showing no evidence of acute intraabdominal pathology.

The patient remained in considerable pain, therefore the scan was rediscussed with a senior radiology consultant; a high attenuation linear foreign body was noted in the mid small bowel, extending beyond the lumen and into the omental fat and associated focal stranding of the small bowel mesentery (figure 1). These were noted to be consistent with a fishbone perforation of the small bowel; on further questioning, the patient did recall eating a bony fish 4 days prior to admission.

As a result, the patient underwent a diagnostic laparoscopy, which did indeed demonstrate a foreign body, most likely a fishbone, perforating the distal small bowel (figure 2), being sealed off by the omentum. There was no obvious collection or contamination of the abdominal cavity, therefore the fishbone was removed and the decision was made to repair the injury with a single layer of interrupted PDS (polydioxanone) 3.0 sutures overlapping the defect. The postoperative recovery
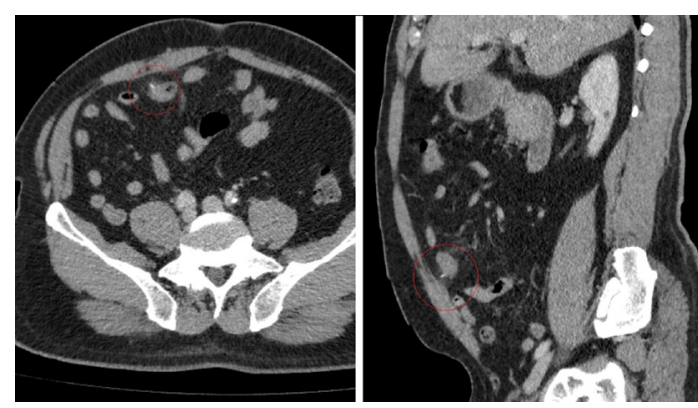

Figure 1 A transverse (left) and sagittal (right) slice of a CT scan of this patient's abdomen, demonstrating radiologically the foreign body perforation.
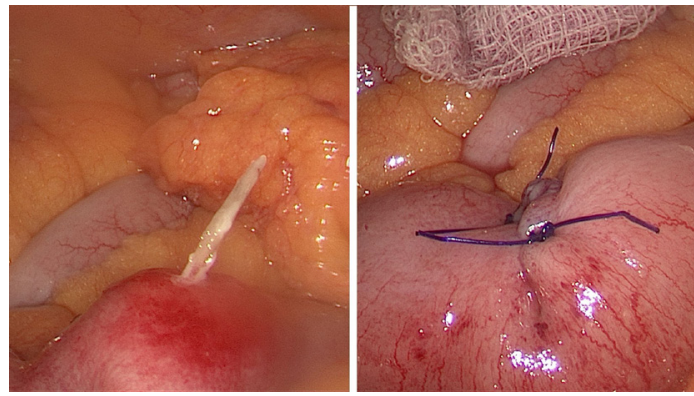

Figure 2 Laparoscopic images demonstrating the perforating fishbone (left) and primary suture repair (right).

\section{Learning points}

- Small bowel perforations by fishbones without any significant bowel injury or contamination can be successfully managed with a primary laparoscopic approach.

- Fishbone bowel perforation is often a difficult radiological diagnosis, therefore, additional radiological opinion should be sought if clinical suspicion remains high.

- Clinicians should maintain a high index of suspicion with unexplained persistent abdominal pain, when there is genuine equipoise regarding a diagnosis.

was unremarkable and the patient was discharged 3 days postoperatively.

Although ingested dietary foreign bodies cause perforation in $<1 \%$ of cases, ${ }^{1}$ they often present a diagnostic challenge due to their subtle and variable radiological appearance. Moreover, patients are often unaware that they have ingested anything to cause such a pathology. ${ }^{2}$ This case highlights the importance of a senior radiological opinion when the clinical picture may not be consistent with the radiological findings. Small bowel perforations by fishbones without any significant bowel injury or contamination can be successfully managed with a primary laparoscopic approach, without requiring any bowel resection.

Contributors MZ: obtained patient consent, wrote first draft, created figures. MB: assistant surgeon during the operation, edited the draft, obtained CT images. GK: primary surgeon during the operation, edited the draft. PG: responsible consultant for the patient, edited the draft.

Funding The authors have not declared a specific grant for this research from any funding agency in the public, commercial or not-for-profit sectors. 
Competing interests None declared.

Patient consent for publication Obtained.

Provenance and peer review Not commissioned; externally peer reviewed.

\section{ORCID iD}

Mohamad Zeina http://orcid.org/0000-0002-8119-1931

\section{REFERENCES}

1 Maleki M, Evans WE. Foreign-Body perforation of the intestinal tract. Report of 12 cases and review of the literature. Arch Surg 1970;101:475-7.

2 Goh BKP, Tan Y-M, Lin S-E, et al. Ct in the preoperative diagnosis of fish bone perforation of the gastrointestinal tract. AJR Am J Roentgenol 2006;187:710-4.

Copyright 2021 BMJ Publishing Group. All rights reserved. For permission to reuse any of this content visit https://www.bmj.com/company/products-services/rights-and-licensing/permissions/

BMJ Case Report Fellows may re-use this article for personal use and teaching without any further permission.

Become a Fellow of BMJ Case Reports today and you can:

- Submit as many cases as you like

- Enjoy fast sympathetic peer review and rapid publication of accepted articles

- Access all the published articles

Re-use any of the published material for personal use and teaching without further permission

Customer Service

If you have any further queries about your subscription, please contact our customer services team on +44 (0) 2071111105 or via email at support@bmj.com.

Visit casereports.bmj.com for more articles like this and to become a Fellow 